\title{
Angiotensin II Type 1 Receptor $A^{1166} \mathrm{C}$ Polymorphism and Prophylactic Indomethacin Treatment Induced Ductus Arteriosus Closure in Very Low Birth Weight Neonates
}

\author{
ANDRÁS TRESZL, MIKLÓS SZABÓ, GYÖRGY DUNAI, ANDRÁS NOBILIS, \\ ISTVÁN KOCSIS, TAMÁS MACHAY, TIVADAR TULASSAY, AND BARNA VÁSÁRHELYI \\ First Department of Pediatrics [A.T., M.S., G.D., I.K., T.M., T.T]; Department of Obstetrics and \\ Gynecology [A.N.]; and Research Laboratory for Pediatrics and Nephrology [B.V.], Semmelweis \\ University, Budapest, Bókay utca 53, H-1083, Hungary
}

\begin{abstract}
Altered pulmonary vascular resistance might be a factor for delayed closure of the ductus arteriosus (DA) in preterm infants. Angiotensin II plays a central role in the elevation of pulmonary vascular resistance. Angiotensin II exerts its vasoconstrictor effect on the angiotensin II type 1 receptor (AT1R). Homozygous carriers of the AT1R A ${ }^{1166} \mathrm{C}$ genetic variant present an exaggerated vasoconstrictor response to angiotensin II. We have investigated whether the presence of AT1R $\mathrm{CC}^{1166}$ influences the effect of prophylactic indomethacin treatment on the closure of DA until the fifth postnatal day in preterm infants. In this retrospective study detailed medical history of the first postnatal week was obtained in 159 infants born before the 33rd gestational week. All were treated by prophylactic indomethacin to induce permanent closure of the DA. On the sixth postnatal day the DA was still open in 56 , whereas it was permanently closed in 103 . The AT1R $\mathrm{A}^{1166} \mathrm{C}$ genotype of the infants was determined from Guthrie spots. Stepwise binary logistic regression analysis was used to assess the effect of medical conditions and genotype on the risk of patent DA (PDA). Birth weight, infantile
\end{abstract}

\section{ABSTRACT}

respiratory distress, and severe hypotension were independent risk factors for PDA ( $p<0.01, p<0.05, p<0.05$, respectively). The carrier state of AT1R $C^{1166}$ was protective against PDA $\left(p<0.05\right.$; odds ratio, 0.067). AT1R AC ${ }^{1166}$ genotype was not associated with PDA. Our results indicate that the risk of PDA might be lower in infants of AT1R $\mathrm{CC}^{1166}$ than in those with AC or AA genotypes. (Pediatr Res 54: 753-755, 2003)

Abbreviations
AngII, angiotensin II
AT1R, AngII type 1 receptors
AT1R A ${ }^{1166} \mathrm{C}$, polymorphism substituting C for A at position
+1166 of $A T 1 R$ gene
DA, ductus arterious
PDA, patent ductus arteriosus
ACE, angiotensin-converting enzyme
PKU, phenylketonuria
IRDS, infantile respiratory distress syndrome

Endogenous vasoactive peptides play a central role in the regulation of pulmonary hemodynamics. So far the effect of AngII on the development of pulmonary hypertension has been studied most extensively (1). Evidence suggests that AngII produces proportionately greater vasoconstriction in the pulmonary than in the systemic vascular bed of healthy humans (2). Plasma concentrations of AngII, the main vasoactive com-

Received December 17, 2001; accepted November 25, 2002.

Correspondence: Barna Vásárhelyi, Ph.D., First Department of Pediatrics, Budapest, Bókay u. 53, H-1083 Hungary; e-mail: vasbar@gyer1.sote.hu

Supported financially by OTKA Grants T031950-F032024, K+F 0134/2001, and ETT-281/2001. Barna Vásárhelyi is a recipient of the Bolyai János Research Grant of the Hungarian Academy of Sciences.

DOI: 10.1203/01.PDR.0000088016.67117.39 ponent of the renin-angiotensin system, are elevated in pulmonary hypertension and may interact with hypoxemia to cause further pulmonary vasoconstriction.

Animal experiments indicate that the vasoconstrictor effect of AngII is mediated by AT1R in the pulmonary artery $(3,4)$. Clinical studies also support that specific inhibition of AT1R is associated with reduced pulmonary vascular resistance in adult patients with heart failure (5-7).

Genetic polymorphisms of the ATIR gene might influence the vasoconstrictor effect of AngII (8). The polymorphism substituting $\mathrm{C}$ for $\mathrm{A}$ at position +1166 was related to enhanced systemic vasoconstriction leading to hypertension $(9,10)$. Data are missing about the impact of the $C^{1166}$ variant of the AngII gene on the effects of AngII at pulmonary vessels, but it seems reasonable to postulate that the presence of this gene polymor- 
phism might be associated with higher pulmonary vascular resistance.

In the neonate the difference between pulmonary and systemic blood pressure influences the complex process of the closure of the DA. Conditions known to be associated with pulmonary hypotension (i.e. pulmonary hemorrhage, low $\mathrm{PaCO}_{2}$ levels, intrauterine ACE inhibitor exposure) augment the long-term patency of the DA (11). Assuming that the presence of the $\mathrm{C}^{1166}$ allele of the $A T 1 R$ gene is associated with elevated pulmonary vascular resistance in the neonate, we have investigated in our pilot study the independent effect of the AT1R genotype on the risk of PDA in preterm neonates.

\section{METHODS}

Patients. The study population was selected from a cohort of neonates born between January 1, 1998, and September 1, 2002, at the Second Department of Gynecology and Obstetrics and at the Schöpf Mérei Women's Hospital. The medical history of low-birth-weight neonates during the first 6 postnatal $\mathrm{d}$ was analyzed in detail. In this retrospective study the following selection criteria were applied: gestational age $\leq 32$ wk; prophylactic dose of indomethacin $\left(0.1 \mathrm{mg} \cdot \mathrm{kg}^{-1} \cdot \mathrm{d}^{-1}\right.$, at least during the first 3 postnatal d); absence of blood transfusion before collecting blood samples for PKU analysis; death before the 28th postnatal d; and excessive volume loading.

The PDA group consisted of 56 neonates in whom echocardiography or clinical signs indicated the presence of PDA after the fifth postnatal day. In these patients, the PDA was closed permanently before the 10th postnatal $\mathrm{d}$ in $11(35 \%)$, was closed after repeated indomethacin treatment in $39(54 \%)$, or was resolved by surgical closure in $6(11 \%)$ patients. The non-PDA group consisted of those 103 neonates in whom the DA had been permanently closed before the sixth postnatal day and had not reopened thereafter.

Surfactant need (at least two doses during the first postnatal day) indicated the presence of IRDS. Severe hypotension was defined as need for catecholamine treatment (with dopamine dose of $\geq 5 \mu \mathrm{g} \cdot \mathrm{kg}^{-1} \cdot \mathrm{d}^{-1}$ or dobutamine dose of $\geq 9$ $\mu \mathrm{g} \cdot \mathrm{kg}^{-1} \cdot \mathrm{d}^{-1}$ ). Perinatal infection was established by clinical and laboratory signs according to the criteria of Modi et al.
(12). Neurologic and ultrasound signs indicated the presence of intraventricular bleeding.

The study was approved by an institutional ethical committee. Informed consent of parents was obtained to collect dried blood samples for diagnostic and scientific purposes at the beginning of the therapy at the neonatal intensive care unit. Blood spots were taken on the fifth postnatal day for screening of PKU and hypothyreosis, then were stored at the PKU laboratory of the Metabolic Screening Program. We used remnant dried blood samples for genotyping. The parents of each patient were Hungarian citizens.

Genotyping. The $\mathrm{Hb}$ content of samples was denatured by heat inactivation according to the method of Szalai et al. (13). For the determination of AT1R A ${ }^{1166} \mathrm{C}$ polymorphism, 5'-ATA ATG TAA GCT CAT CCA CCA AGA AG-3' and 5'-TCT CCT TCA ATT CTG AAA AGT ACT TAA-3' primers were used (14). PCR began with denaturation at $94^{\circ} \mathrm{C}(4 \mathrm{~min})$, followed by 35 cycles of denaturation at $94^{\circ} \mathrm{C}(0.5 \mathrm{~min})$, annealing at $50^{\circ} \mathrm{C}(1 \mathrm{~min})$, and extension at $72^{\circ} \mathrm{C}(1 \mathrm{~min})$ and a final extension at $72^{\circ} \mathrm{C}(10 \mathrm{~min})$. PCR products were restricted with Afl-II (New England Biolabs, Beverly, MA, U.S.A.). PCR products were separated on $3 \%$ agarose gels and visualized under UV illumination.

Statistical analysis. Clinical characteristics between PDA and non-PDA patients were compared by Mann-Whitney $U$ test. Categorical data were analyzed by $\chi^{2}$ test. Stepwise binary logistic regression analysis was applied to determine the independent effect of birth weight, intraventricular bleeding, Apgar scores, perinatal infection, severe hypotension, IRDS, and AT1R $\mathrm{C}^{1166}$ genotype on PDA. The level of significance was set at $p<0.05$.

\section{RESULTS}

Our results are summarized in Table 1. Factors significantly affecting the development of PDA are birth weight (odds ratio [confidence interval]; 0.996 [0.994-0.999], $p=0.002)$, IRDS (2.976 [1.052-8.415], $p=0.040)$, severe hypotension (3.858 $[1.348-11.044], p=0.012)$, and the presence of $C^{1166}(0.067$ [0.005-0.821], $p=0.035)$. Apgar scores, intracerebral bleed-

Table 1. Clinical characteristics and ATIR $A^{1166}$ C genotype of low-birth-weight infants with or without PDA after the fifth postnatal day

\begin{tabular}{lcc}
\multicolumn{1}{c}{ Characteristic } & $\begin{array}{c}\text { Infants with PDA after } \\
\text { the fifth postnatal day } \\
(n=56)\end{array}$ & $\begin{array}{c}\text { Infants without PDA after } \\
\text { the fifth postnatal day } \\
(n=103)\end{array}$ \\
\hline $\begin{array}{l}\text { Permanent closure of DA after fifth postnatal day } \\
\text { Gestational age (wk) [median, range] }\end{array}$ & 0 & 103 \\
Tested factors for PDA at the sixth postnatal day & $28[24-32]$ & $30-32]^{*}$ \\
Birth weight (g) [median, range] & $1100[650-1500]$ & $1240[870-1500]^{*}$ \\
Apgar 1/Apgar 5 & $5.75 / 7.92$ & $6.25 / 8.25$ \\
IRDS & 38 & 55 \\
Severe hypotension广 & 25 & 33 \\
Perinatal infection & 20 & 25 \\
Intraventricular hemorrhage stage & 21 & 25 \\
Prevalence of AT1R C & 0.18 \\
Number of patients with AT1R ${ }^{1166}$ (AA/AC/CC) genotype & $36 / 20 / 00$ & 0.27 \\
\hline
\end{tabular}

* Significantly different $(p<0.05)$ between PDA and non-PDA infants.

$\dagger$ Catecholamine treatment (with dopamine dose of $\geq 5 \mu \mathrm{g} \cdot \mathrm{kg}^{-1} \cdot \mathrm{min}^{-1}$ or dobutamine dose of $\geq 9 \mu \mathrm{g} \cdot \mathrm{kg}^{-1} \cdot \min ^{-1}$ ). 
ing, and perinatal infection were not associated with higher risk in this study.

The prevalence of AT1R $\mathrm{C}^{1166}$ alleles was 0.18 in PDA and 0.27 in non-PDA infants $(p<0.05)$. The prevalence of carriers of AT1R C mutant allele was 0.36 in PDA and 0.41 in non-PDA neonates. AT1R CC genotype occurred significantly more frequently in non-PDA than in PDA neonates (13 of 103 versus 0 of $56, p<0.05)$. PDA did not develop in any of the 13 infants with the AT1R CC genotype. No difference was found between the risk factors in infants with or without $\mathrm{CC}^{1166}$ genotype (data not shown).

\section{DISCUSSION}

Persistent PDA is a frequent complication of immaturity, especially in babies born before the 33rd week of gestation. In this pilot study we have investigated the prevalence and distribution of the AT1R $\mathrm{C}^{1166}$ genotype in low-birth-weight infants with PDA and tested whether carrying this genotype is independently associated with PDA risk. Our results show that in addition to immaturity and IRDS, the AT1R $\mathrm{CC}^{1166}$ genotype might play an independent role in the development of PDA.

The underlying mechanism is still to be elucidated. Speculatively, there are two possibilities. On the one hand, AngII might have a direct effect on the DA itself. However, data are not available about whether AT1R is expressed on smooth muscle cells of the ductal wall at all. The indirect effect of AngII on the patency of the DA seems to be more reasonable. Literary data indicate that AngII is a potent vasoconstrictor of pulmonary arteries. Preventing the production of AngII, ACE inhibitor therapy leads to pulmonary hypotension in adults (15). Indirect data also support the significance of the reninangiotensin system in closure of the DA. ACE inhibitor treatment of pregnant women was associated with PDA in the neonate (16).

\section{CONCLUSIONS}

AngII exerts its hemodynamic effects mainly on the $A T 1 R$ gene. The AT1R CC genotype was related to a markedly increased response to exogenously given AngII (17), but data supporting the significance of AngII receptor polymorphism in the regulation of pulmonary vascular bed are not available. On the basis of our preliminary results it is tempting to speculate that the AT1R $\mathrm{CC}^{1166}$ genotype in neonates born before the 33rd gestational week might be associated with more favorable hemodynamic conditions for the cessation of the left-to-right shunt and for the permanent closure of the DA.

Acknowledgments. The authors thank Dr. László Zubovics from Schöpf-Mérei Women's Hospital for his help in the enrollment of patients and Dr. Ágnes Schuler from PKU laboratory for her help in obtaining blood samples.

\section{REFERENCES}

1. Cargill RI, Lipworth BJ 1995 The role of the renin-angiotensin and natriuretic peptide systems in the pulmonary vasculature. Br J Clin Pharmacol 40:11-18

2. Lipworth BJ, Dagg KD 1994 Vasoconstrictor effects of angiotensin II on the pulmonary vascular bed. Chest 105:1360-1364

3. Tan LM, Sim MK 2000 Actions of angiotensin peptides on the rabbit pulmonary artery. Life Sci 66:1839-1847

4. Kaye AD, Nossaman BD, Smith DE, Ibrahim IN, Anwar M, Kadowitz PJ 1998 Analysis of responses to angiotensin I (3-10) and Leu3 angiotensin (3-8) in the pulmonary vascular bed of the cat. Am J Ther 5:295-302

5. Morrell NW, Upton PD, Higham MA, Yacoub MH, Polak JM, Wharton J 1998 Angiotensin II stimulates proliferation of human pulmonary artery smooth muscle cells via the AT1 receptor. Chest 114(suppl):90S-91S

6. Kiely DG, Cargill RI, Wheeldon NM, Coutie WJ, Lipworth BJ 1997 Haemodynamic and endocrine effects of type 1 angiotensin II receptor blockade in patients with hypoxaemic cor pulmonale. Cardiovasc Res 33:201-208

7. Clair MJ, Krombach RS, Hendrick JW, Houck WV, Hebbar L, Kribbs SB, Rios G, Whitebread S, Mukherjee R, de Gasparo M, Spinale FG 1998 AT1 angiotensin II receptor inhibition in pacing-induced heart failure: effects on left ventricular performance and regional blood flow patterns. J Card Fail 4:311-323

8. Duncan JA, Scholey JW, Miller JA 2001 Angiotensin II type 1 receptor gene polymorphisms in humans: physiology and pathophysiology of the genotypes. Curr Opin Nephrol Hypertens 10:111-116

9. Hingorani AD, Jia H, Stevens PA, Hopper R, Dickerson JE, Brown MJ 1995 Renin-angiotensin system gene polymorphisms influence blood pressure and the response to angiotensin-converting enzyme inhibition. J Hypertens 13:1602-1609

10. Kainulainen K, Perola M, Terwilliger J, Kaprio J, Koskenvuo M, Syvanen AC, Vartiainen E, Peltonen L, Kontula K 1999 Evidence for involvement of the type 1 angiotensin II receptor locus in essential hypertension. Hypertension 33:844-849

11. Kluckow M, Evans N 2000 Ductal shunting, high pulmonary blood flow, and pulmonary hemorrhage. J Pediatr 137:68-72

12. Modi N 1999 Disorders of the kidney and urinary tract. In: Rennie JM, Roberton NRC (eds): Textbook of Neonatology. Churchill-Livingston, Edinburgh, pp 1009-1037

13. Szalai C, Czinner A, Révai K 1996 The frequency of medium-chain acyl-CoA dehydrogenase G985 mutation in the Hungarian population. Eur J Pediatr 155:256

14. Szombathy T, Jánoskúti L, Szalai C, Császár A, Miklósi M, Mészáros Z, Kempler P, László Z, Fenyvesi T, Romics L 2000 AII type 1 receptor gene polymorphism and mitral valve prolapse syndrome. Am Heart J 139:101-105

15. Krombach RS, Clair MJ, Hendrick JW, Houck WV, Zellner JL, Kribbs SB, Whitebread S, Mukherjee R, de Gasparo M, Spinale FG 1998 Angiotensin-converting enzyme inhibition, AT1 receptor inhibition, and combination therapy with pacinginduced heart failure: effects on left ventricular performance and regional blood flow patterns. Cardiovasc Res 38:631-645

16. Barr M 1994 Teratogen update: angiotensin-converting enzyme inhibitors. Teratology 50:399-409

17. Miller JA, Thai K, Scholey JW 1999 Angiotensin II type 1 receptor gene polymorphism predicts response to losartan and angiotensin II. Kidney Int 56:2173-2180 